\title{
Comparison of ER, PR \& HER2/neu(C-erb B2) reactivity pattern with various histomorphological patterns in patients with breast cancer
}

\author{
Alpesh M. Maru', Atul Shrivastava ${ }^{2, *}$, Tejas Chokshi $^{3}$, A. S. Agnihotri ${ }^{4}$ \\ ${ }^{1}$ Assistant Professor, ${ }^{2}$ Associate Professor, ${ }^{3}$ Professor, ${ }^{4}$ Professor \& HOD, Dept. of Pathology, ${ }^{1}$ GMERS Medical \\ College, Junagadh, Gujarat, ${ }^{2}$ GMERS Medical College, Himmatanagar, Gujarat, ${ }^{3,4} \mathrm{C}$. U. Shah Medical College, \\ Surendranagar, Gujarat, India
}

*Corresponding Author:

Email: drmaru28@gmail.com

\begin{abstract}
Introduction: Globally carcinoma breast is the leading cause of cancer death in women .Prognosis of such patients is related to a variety of Histomorphological features which includes, Histological grade, type, tumor size and lymph node metastases. Estrogen and progesterone receptors (ER, PR) and more recently, HER-2/neu have with increasing importance influenced the management of the malignancy.

Materials and Methods: This study was carried out at tertiary care hospital which included 70 cases of breast cancer that we have reported at our department during a period from June 2012 to June 2014.Specimens were fixed overnight in $10 \%$ Neutral buffered formalin and processed as routine for H\&E staining. Representative sections with tumour with adjacent normal breast tissue (internal control) were taken on Poly-L-Lysine coated slides and proceed for antigen retrieval, HRP Polymerization steps and than processed for ER, PR and HER-2/neu immuno-histochemical staining with respective antibody.

Observation and Results: Maximum No. Of cases were in age group 5th and 6th decade with Invasive ductal carcinoma was predominately observed followed by invasive lobular carcinoma. Among 70 cases, 25 cases (35.71\%) showing ER/PR+ HER 2pattern which is predominant pattern in this study. While 23 cases $(32.85 \%)$ showing Tripple negative pattern.

Conclusion: most important cost effective, prognostic markers are estrogen receptor status, progesterone receptor status and HER2/neu status. Correlation of these marker status with clinical parameters helps in predicting the future treatment modalities and disease free survival for the patient in developing countries.
\end{abstract}

Keywords: ER-Estrogen receptor, PR-Progesteron recptor, Immunohistochemistry.

\section{Introduction}

Carcinoma breast is second leading cause of cancer death of women in India. ${ }^{1}$ Clinically patients presented with breast lump and other constitutional symptoms. Early detection and proper treatment modalities are necessary for good survival. Prognosis of such patients based on age, histological pattern, grading, nodal status and recent diagnostic modality like Immunohistochemistry(IHC). ${ }^{2}$ ER(Estrogen Receptor), PR(Progesterone receptor) \& HER2/neu [Human epidermal receptor -2 neural differentiation] receptors are well established prognostic markers for carcinoma breast. It not only helps in the prognosis of the tumor but also helps in deciding its treatment.The goal of performing this receptor status is to provide right treatment to the right patient.Two classes of ER exist: nuclear estrogen receptors (ER $\alpha$ and $E R \beta)$, which are members of the nuclear receptor family of intracellular receptors, and membrane estrogen receptors (mERs), which are $\mathrm{G}$ protein-coupled receptors.PR is encoded by a single PGR gene residing on chromosome 11q22, these receptors are found on breast cells that pick up hormone signals resulting in cell growth. Cancer is called ER-positive, if it has receptors for hormone estrogen which receives the signals from estrogen and promotes its growth, just like normal cells. Similarly, the cancer is PR-positive, if it has receptors for hormone progesterone. HER $2 /$ neu protein overexpression means too many HER2/neu receptors that makes breast cells to grow and divide in an uncontrolled way.

ER and PR are hormonal markers showing positivity on well differentiated tumors \& associated with good outcome., ${ }^{3,4}$ HER2/neu is known as oncogenes\& its overexpression is associated with poor outcome which shows positivity on poorly differentiated tumors with responsive to chemotherapy and Herceptin. ${ }^{5}$

\section{Objectives}

1. To study correlation between IHC markers positivity and prognosis of patients.

2. To study correlation between IHC markers and their association with other histomorphological parameters like nuclear grade, tumor size $\&$ age of patients.

\section{Materials and Methods}

This study was conducted in pathology department of C. U. Shah Medical College \& Hospital, Surendranagar. The study was carried out on 70 patients, who had undergone surgery for carcinoma breast. All histopathologically diagnosed cases of breast carcinoma referred to our department during June 2012 to June 2014 were included in this study. They were referred mostly from surgery department \& few from 
peripheral centers. Specimens were fixed in $10 \%$ Neutral Buffered Formalin(NBF) \& grossing done with standard surgical guidelines. After tissue processing, 4$5 \mu \mathrm{m}$ thick sections \& stained with routine $\mathrm{H} \& \mathrm{E}$. Reporting done according to WHO classification of breast tumors \& grading done according to Nottingham modified Bloom-Richardson system ${ }^{6}$ which is based on tubule formation, nuclear grade \& mitoses. For Immunohistochemistry, tumor sections were taken on Poly-L-Lysine coated frosted slides rather than egg albumin coated slides. Aafter dewaxing and three steps of Alcohol, we proceed for Antigen retrieval(AR) which was done with citrate buffer on pressure cookers. After that we pour rabbit monoclonal antibody(SP1Clone) against ER,PR \& HER2/neu antigen \& final steps with HRP polymerization and counter stain with DAB chromogen. Reporting system of IHC slides for ER/PR markers is shown in Table 1 which is based on Allred score ${ }^{[7,8]}$ Reporting of HER2/neu staining based on guidelines of American society of clinical oncology 9,10 as per below chart which states that IHC $3+$ positive means intense, complete, circumferential membrane staining $\geq 10 \%$ of tumor cells, IHC $2+$ positive or equivocal means weak, incomplete, circumferential membrane staining $\geq 10 \%$ of tumor cells,IHC $1+$ negative means faint, incomplete, membrane staining $\geq 10 \%$ of tumor cells while IHC grade 0 means no staining of tumor cells. Following chart-1 showing HER2/neu reporting pattern.

\section{Chart 1: HER2/neu reporting system}

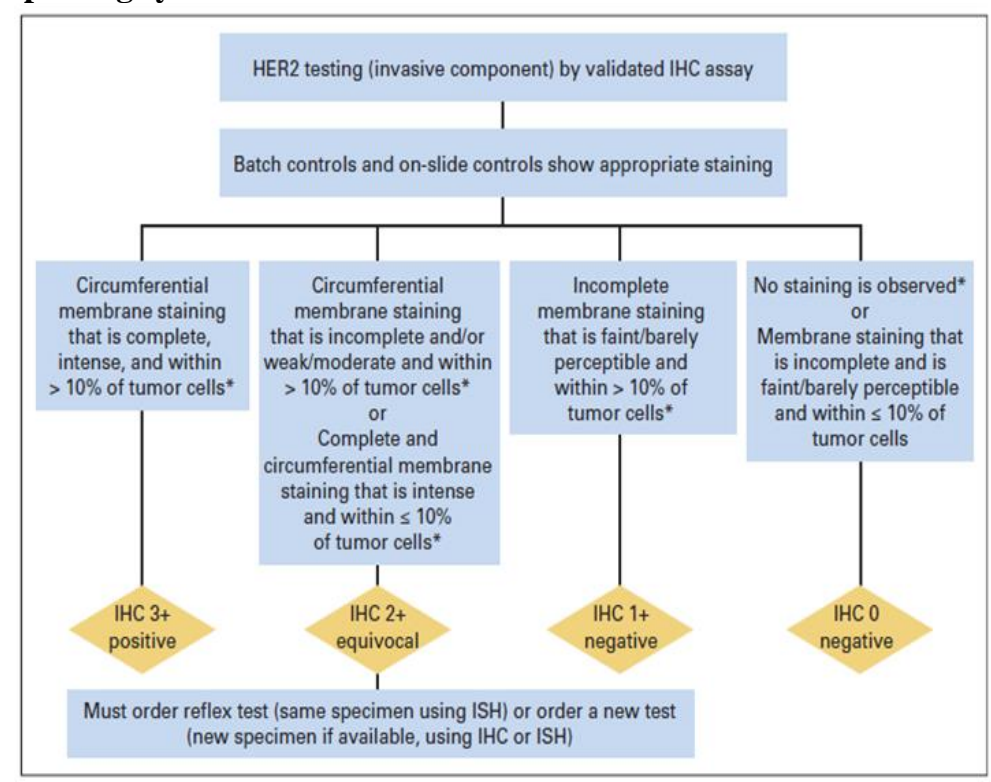

Table 1: The ER/PR scoring system and criteria-Allred Method

Total Score $=$ PS+IS

\begin{tabular}{|c|l|c|l|c|}
\hline \multicolumn{2}{|c|}{ Proprtional Score (PS) } & \multicolumn{2}{|l|}{ Intensity Score (IS) } & Total Score \\
\hline PS & \% of Nuclear staining & IS & Nuclear Staining Intensity & TS = PS+IS \\
\hline 0 & No Staiing & 0 & No Staining & \\
\hline 1 & $0-1 \%$ & 1 & Weak & \\
\hline 2 & $2-10 \%$ & 2 & Intermediate & \\
\hline 3 & $11-35 \%$ & 3 & Strong & \\
\hline 4 & $36-70 \%$ & & & \\
\hline 5 & $71-100 \%$ & & & \\
\hline
\end{tabular}

$0-2$ : Negative

3-8: Positive

\section{Observations and Results}

This study was conducted in pathology department of C. U. Shah Medical College \& Hospital, Surendranagar from July 2012 to August 2014 included 70 cases of breast cancer. Among them maximum no. of cases were in age group $4^{\text {th }}$ and $5^{\text {th }}$ decade.(Fig. 1) and out of 70 specimens we received, $71.43 \%$ were
MRM specimens. As we seen in table 2, Among 70 cases, invasive ductal carcinoma(IDC) was most common observed pattern (52 cases, $74.28 \%$ ) followed by invasive lobular carcinoma $(5.71 \%)$.

Out of 70 Patients, Right sided involvement of breast was observed in 37 case, while 33 cases had Left sided involvement of breast. 
Among 70 cases, 29 cases $(41.42 \%)$ reported with tumor size was $\leq 4 \mathrm{~cm}$ and majority cases were reported in $4^{\text {th }}$ decades. Whereas 41 cases $(58.57 \%)$ having tumor size $>4 \mathrm{~cm}$ with majority cases were reported in $5^{\text {th }}$ decades

Maximum numbers of ER/PR positivity was observed in $4^{\text {th }}$ decade and Maximum number of ER/PR negativity seen in $5^{\text {th }}$ decade. (peri menopausal). (Table 3)

Among 52 cases of invasive ductal carcinoma, 26 were showing ER Positivity \& 28 were showing PR positivity and HER2/neu positivity observed in 20 cases. Out of four patients with invasive lobular carcinoma, two were triple negative \& two shows
ER/PR +ve,HER2/neu -ve pattern, while cases of medullary carcinoma and metaplastic squamous cell carcinoma of breast showing triple negative pattern(Table 4). Maximum number of ER/PR positivity was reported in well differentiated carcinoma and maximum number of HER-2 positivity was reported in poorly differentiated invasive carcinoma.

Among 70 cases, 25 cases $(35.71 \%)$ showing $\mathrm{ER} / \mathrm{PR}+\mathrm{HER} 2$ - pattern which is predominant pattern in this study. While 23 cases $(32.85 \%)$ showing triple negative pattern which is $2^{\text {nd }}$ common pattern in this study. We had also observed ER/PR -ve,HER 2+ve pattern in 11 patients with carcinoma breast while 9 cases were observed as triple positive.(Fig. 2)

Fig. 1: Age range in present study $(n=70$ cases $)$

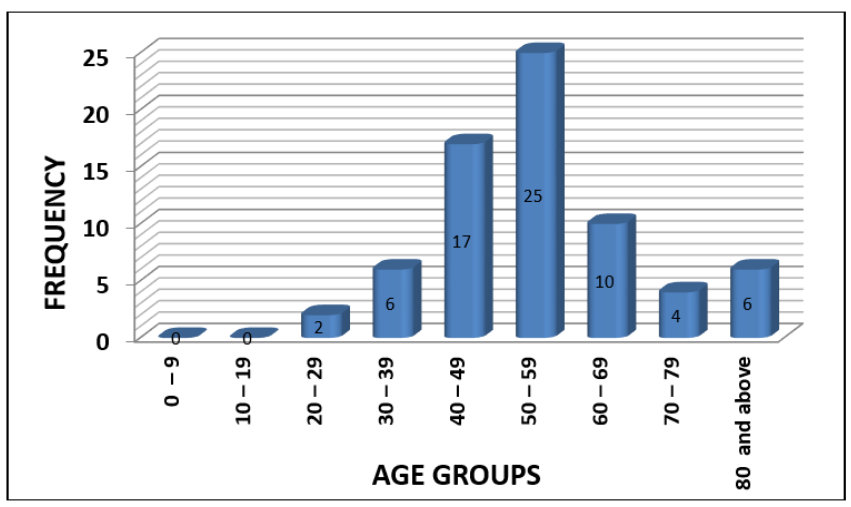

Table 2: Histopathology diagnosis $(n=70$ cases) of malignant breast lesions

\begin{tabular}{|l|c|c|}
\hline \multicolumn{1}{|c|}{ Histological diagnosis } & No. of cases & Percentage (\%) \\
\hline IDC - NOS type & 52 & 74.28 \\
\hline Invasive lobular carcinoma & 04 & 05.71 \\
\hline IDC with neuroendocrine diff. & 03 & 04.28 \\
\hline IDC with Comedo carcinoma & 03 & 04.28 \\
\hline Medullary carcinoma & 02 & 02.86 \\
\hline Mucinous(colloid) carcinoma & 01 & 01.43 \\
\hline Papillary carcinoma Breast & 02 & 02.85 \\
\hline Metaplastic Squamous cell carcinoma & 02 & 02.85 \\
\hline Paget's Carcinoma & 01 & 01.43 \\
\hline Total & 70 & \\
\hline
\end{tabular}

Table 3: Age distribution of ER/PR status in carcinoma breast ( $n=70$ cases)

\begin{tabular}{|l|c|c|c|}
\hline $\begin{array}{c}\text { Age range } \\
\text { (Years) }\end{array}$ & $\begin{array}{c}\text { Total No. } \\
\text { of cases }\end{array}$ & ER/PR +ve & ER/PR-ve \\
\hline $0-9$ & 00 & 00 & 00 \\
\hline $10-19$ & 00 & 00 & 00 \\
\hline $20-29$ & 02 & 00 & 02 \\
\hline $30-39$ & 06 & 04 & 02 \\
\hline $40-49$ & 17 & 10 & 07 \\
\hline $50-59$ & 25 & 07 & 18 \\
\hline $60-69$ & 10 & 06 & 04 \\
\hline $70-79$ & 04 & 04 & 00 \\
\hline$\geq 80$ & 06 & 02 & 04 \\
\hline Total & 70 & 33 & 37 \\
\hline
\end{tabular}


Table 4: Comparison of Marker positivity with Histopathological types

\begin{tabular}{|c|c|c|c|c|c|c|c|}
\hline \multirow{2}{*}{$\begin{array}{c}\text { Histological } \\
\text { diagnosis }\end{array}$} & \multirow{2}{*}{$\begin{array}{l}\text { Total } \\
\text { cases }\end{array}$} & \multicolumn{2}{|c|}{ ER } & \multicolumn{2}{|c|}{ PR } & \multicolumn{2}{|c|}{ HER2neu } \\
\hline & & +ve & -ve & +ve & -ve & +ve & -ve \\
\hline IDC-NOS type & 52 & $26(50 \%)$ & $26(50 \%)$ & $28(53.84 \%)$ & $24(46.15 \%)$ & $20(38.46 \%)$ & $32(61.53 \%)$ \\
\hline $\begin{array}{l}\text { Invasive } \\
\text { Lobular } \\
\text { carcinoma }\end{array}$ & 04 & $02(50 \%)$ & $02(50 \%)$ & $02(50 \%)$ & $02(50 \%)$ & $00(0 \%)$ & $04(100 \%)$ \\
\hline $\begin{array}{l}\text { IDC with } \\
\text { Neuroendocrine } \\
\text { diff. }\end{array}$ & 03 & $02(66.6 \%)$ & $01(33.3 \%)$ & $02(66.6 \%)$ & $01(33.3 \%)$ & $00(0 \%)$ & $03(100 \%)$ \\
\hline $\begin{array}{l}\text { IDC with } \\
\text { comedo } \\
\text { carcinoma }\end{array}$ & 03 & $01(33.3 \%)$ & $02(66.6 \%)$ & $01(33.3 \%)$ & $02(66.6 \%)$ & $01(33.3 \%)$ & $02(66.6 \%)$ \\
\hline $\begin{array}{l}\text { Medullary } \\
\text { carcinoma }\end{array}$ & 02 & $00(0 \%)$ & $02(100 \%)$ & $00(0 \%)$ & $02(100 \%)$ & $00(0 \%)$ & $02(100 \%)$ \\
\hline $\begin{array}{l}\text { Mucinous(Collo } \\
\text { id) carcinoma }\end{array}$ & 01 & $01(100 \%)$ & $00(0 \%)$ & $01(100 \%)$ & $00(0 \%)$ & $00(0 \%)$ & $01(100 \%)$ \\
\hline $\begin{array}{l}\text { Papillary } \\
\text { carcinoma }\end{array}$ & 02 & $01(50 \%)$ & $01(50 \%)$ & $01(50 \%)$ & $01(50 \%)$ & $00(0 \%)$ & $02(100 \%)$ \\
\hline $\begin{array}{l}\text { Metaplastic } \\
\text { squamous cell } \\
\text { carcinoma }\end{array}$ & 02 & $00(50 \%)$ & $02(100 \%)$ & $00(0 \%)$ & $02(100 \%)$ & $00(0 \%)$ & $02(100 \%)$ \\
\hline $\begin{array}{l}\text { Paget's } \\
\text { carcinoma }\end{array}$ & 01 & $01(100 \%)$ & $00(0 \%)$ & $01(100 \%)$ & $00(0 \%)$ & $00(0 \%)$ & $01(100 \%)$ \\
\hline Total & 70 & $\begin{array}{c}34 \\
(48.5 \%) \\
\end{array}$ & $\begin{array}{c}36 \\
(51.42 \%)\end{array}$ & $\begin{array}{c}36 \\
(51.42 \%)\end{array}$ & $\begin{array}{c}34 \\
(48.5 \%) \\
\end{array}$ & $\begin{array}{c}21 \\
(30 \%)\end{array}$ & $\begin{array}{c}49 \\
(70 \%)\end{array}$ \\
\hline
\end{tabular}

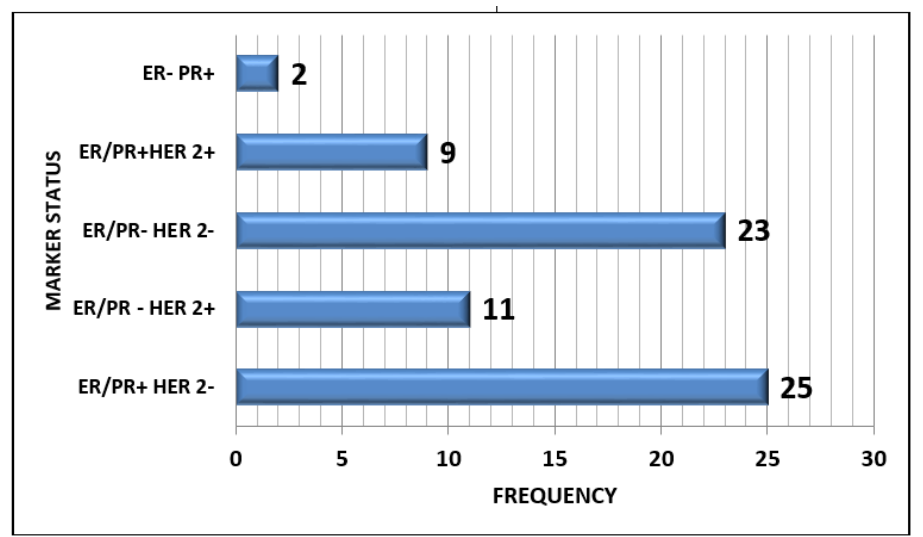

Fig. 2: Pattern of IHC receptor positivity in carcinoma breast. (n=70cases)

\section{Morphological findings}

Invasive ductal carcinoma-NOS type: Out of 70 cases, there were 52 cases reported as IDC- NOS. On histopathology: section shows tumor cells arranged in sheets, cords, clusters \& forming solid, infiltrating pattern. Nuclei of tumor cells are highly pleomorphic, round, vesicular nuclei with multiple nucleoli. At places, atypical mitosis are also seen. They may have associated DCIS[Ductal carcinoma in situ] component. Associated DCIS is often of high grade comedo type, but all other patterns may be seen. (Fig. 3)

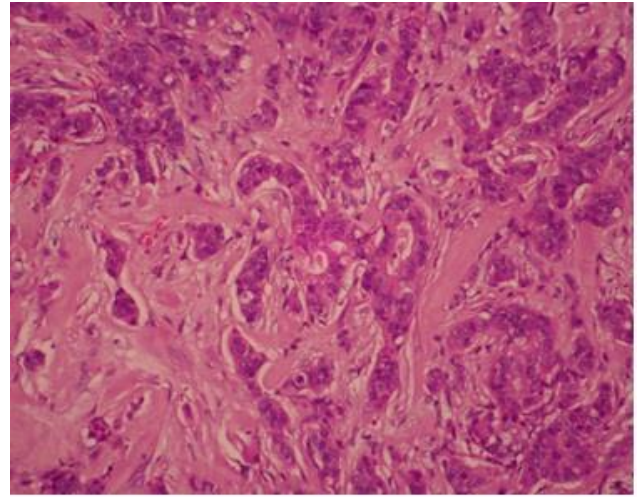

Fig. 3: IDC NOS type: section shows infiltrating pattern of tumor cells: (H\&E X 100) 
Medullary carcinoma: 2 cases of medullary carcinoma were reported, Section showed sheets of cells arranged in syncytial pattern with pushing border, lymphocytic infiltrate in surrounding fibrous septa, nuclear grade high and with no ductal component, so medullary carcinoma have been reported.

IDC with Comedocarcinoma: 3cases of comedo carcinoma were reported, Section showed tumor cell pattern as that of IDC with areas of calcification and necrosis are evident.

IDC with neuroendocrine (NE) differentiation: 3 cases were reported as IDC with neuroendocrine differentiation. Most NE breastcarcinomas form alveolar structures or sheets of tumor cells forming either Palisading, nesting or Rosseting \& having salt $\&$ paper type of nuclear chromatin pattern .

Invasive lobular carcinoma: Out of 70 cases four cases reported as Invasive lobular carcinoma breast.Section shows sheets of cells with high Nuclear: Cytoplasmic ratio, fine granular chromatin and Indian file pattern with desmoplastic reaction (Fig 4).

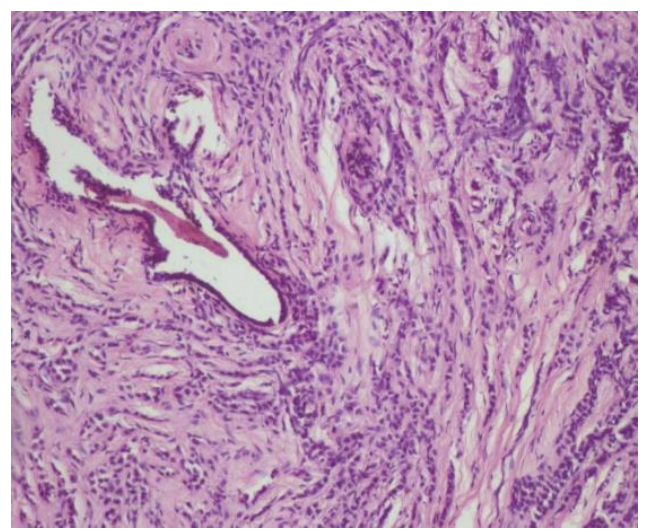

Fig. 4: Invasive Lobularcarcinoma of breast shows typicalIndianfilepattern of tumor cells(H\&E x 100)

Mucinous carcinoma: One case was reported as mucinous carcinoma. Section shows pools of mucin with floating of malignant cells (low grade) in mucin.

Metaplastic Squamous cell carcinoma: Two cases were reported. Sections show metaplastic squamous cells that may be keratinizing, non- keratinizing or spindled; they are not derived from the overlying skin $\&$ also they are not represent metastases from other sites.

Pagets' carcinoma: One case was reported. Section show large clear cells (Pagetoid cells) with atypical nuclei are seen within the epidermis. The cells can be isolated or in clusters, and it may form small glandular structures

Papillary carcinoma breast: Two cases were reported which shows arborizing nature of this tumor and the stout fibrovascular core. Cells are showing atypia with some cells having clear nuclei, atypical mitoses and stromal invasion.
Estrogen receptor: 34 out of 70 - cases were reported as ER positive having Nuclear Positivity. (Fig. 5).

Progesterone receptor: 36 out of 70 cases were reported as PR positive having Nuclear Positivity.

HER2neu receptor: 21 out of 70 cases were reported as HER2neu positive having membranous positivity. (Fig. 6).

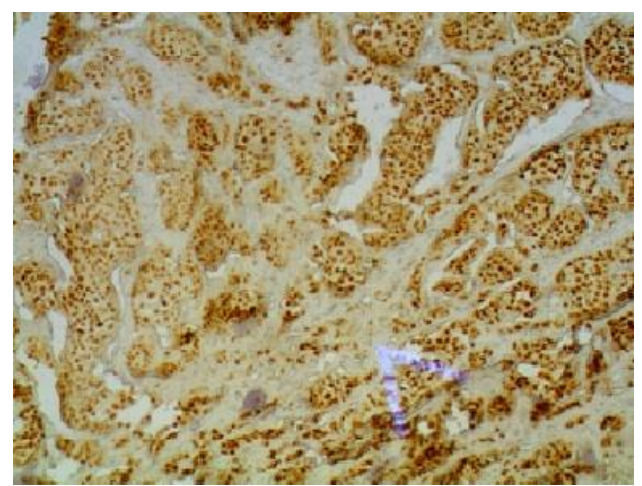

Fig. 5: Shows ER(Nuclear) Positivity(DAB chromogen $X$ 100)

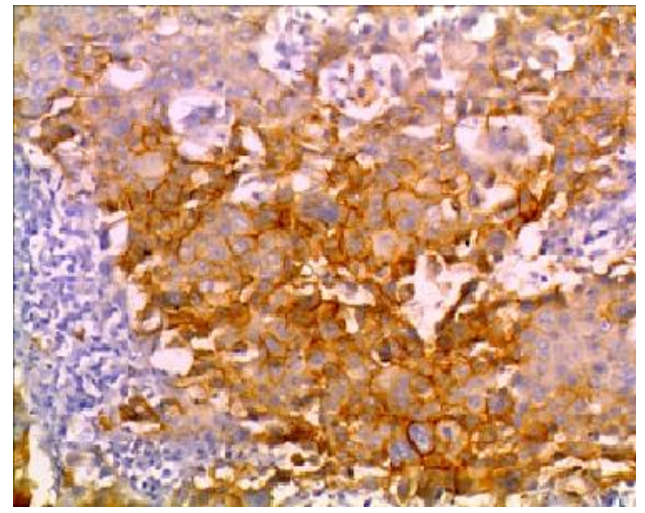

Fig. 6: Shows HER2neu (Membranous) Positivity (DAB chromogen $X$ 100)

\section{Discussion}

In present study method used was fixation of tissue by $10 \%$ neutral buffer formalin, paraffin embedding and $5 \mu \mathrm{m}$ sections on poly L lysine coated slides. IHC staining by polymer HRP - IHC detection system, DAB chromogen, which was in accordance with other studies ${ }^{11,12,13}$ Vang et $\mathrm{al}^{12}$ have performed FISH along with IHC as comparative study. O'malley et al ${ }^{11}$ have compare IHC with quantitative PCR. Shet et al ${ }^{13}$ have perform by avidin - biotin method, and madduwa ${ }^{14}$ have performed by straptavidin biotin method, dako kit.

In our study $74.28 \%$ of cases were ductal carcinoma, followed by $5.71 \%$ lobular carcinoma and $20 \%$ were other histologic types including medullary, mucinous carcinoma, papillary and metaplastic squamous cell carcinoma. PritiLal et $\mathrm{al}^{15}$ also had similar results as observed in our study.

In our study of 70 cases of breast carcinoma, majority of the patients were between the age group of 
40- 59 years with the mean age of 47.2 years. This finding is similar to studies of Azizun- Nisa et $\mathrm{al}^{16}$ (48.3 years).In present study ER negative tumor was higher $(51.42 \%)$ that was in accordance with other studies Like Madduwa et al $^{14}$ reported $53.3 \%$ ER negative cases and Desai et al $^{17}$ reported $67.4 \%$ cases of ER negative. While study result of Allemani et al ${ }^{18}$ is little differ from our study shows 52\% ER Positive cases. Our study shows that PR marker positivity was slight higher $(51.42 \%)$ than PR negativity $(48.58 \%)$ that was in accordance with other studies like Sheth et al ${ }^{13}$ showing $53.9 \%$ PR positive cases \& Dutta et al ${ }^{19}$ showing $55 \%$ cases of PR positivity.

In our study only $30 \%$ cases shows HER-2/neu positivity, that was in accordance with other studies like Vang et al ${ }^{[12]}$ shows $13.20 \%$ Positive cases, Madduwa et $\mathrm{al}^{14}$ shows $19.11 \%$ positive cases \& Jacobs et $\mathrm{al}^{20}$ shows only $23.24 \%$ positivity. Her $-2 / \mathrm{Neu}$ positivity increase in high grade and invasive carcinoma.In the present study HER-2 positivity were high with poor differentiation and invasive carcinoma that was in accordance with other studies. ${ }^{11,12,19}$ Like study of Vang et $\mathrm{al}^{12}$ shows 23 positive cases of HER2/neu markers out of 92 poorly differentiated tumors while study of O'malley et al ${ }^{11}$ shows 38 out of 137 cases of poorly differentiated tumors shows HER2/neu positivity, these findings are well correlated with our study [Table 5].

Table 6 shows that, in present study ER/PR positivity was high with well differentiated carcinoma of breast and ER/PR negative pattern was found in poorly differentiated tumors that was correlated with other study like Dutta et $\mathrm{al}^{19}$ shows that four out of eight cases of well differentiated tumors shows ER/PR positivity, while only three out of ten cases of poorly differentiated carcinoma shows ER/PR positivity.

Table 5: Comparison of Histological grade and HER2neu positivity with other studies

\begin{tabular}{|c|c|c|c|c|c|c|c|c|}
\hline \multirow{2}{*}{$\begin{array}{l}\text { Histological grade } \\
\text { (differentiation) }\end{array}$} & \multicolumn{2}{|c|}{ Vang et al ${ }^{12}$} & \multicolumn{2}{|c|}{ O'malley et al ${ }^{11}$} & \multicolumn{2}{|c|}{ Dutta et al ${ }^{19}$} & \multicolumn{2}{|c|}{ Present study } \\
\hline & Total & $+\mathrm{ve}$ & Total & $+v e$ & Total & $+\mathrm{ve}$ & Total & + te \\
\hline Well & 56 & 00 & 25 & 00 & 08 & 02 & 32 & 00 \\
\hline Moder & 66 & 04 & 92 & 47 & 57 & 34 & 14 & 01 \\
\hline Poor & 92 & 23 & 137 & 38 & 10 & 07 & 24 & 20 \\
\hline Total & 234 & 27 & 232 & 85 & 75 & 43 & 70 & 21 \\
\hline
\end{tabular}

Table 6: Comparison of Histological grade and ER/PR positivity with other studies

\begin{tabular}{|l|c|c|c|c|}
\hline Histological grade & \multicolumn{2}{|c|}{ Dutta et $^{\mathbf{1 9}}$} & \multicolumn{2}{c|}{ Present study } \\
\cline { 2 - 5 } & Total & +ve & Total & +ve \\
\hline Well & 08 & 04 & 32 & 27 \\
\hline Moderate & 57 & 18 & 14 & 06 \\
\hline Poor & 10 & 03 & 24 & 00 \\
\hline Total & 75 & 25 & 70 & 33 \\
\hline
\end{tabular}

\section{Conclusion}

Breast cancer is second leading cause of cancer related deaths in women of India. Even with advances in early detection methods, Mortality rate of breast cancer has remain relatively unchanged over the past several decades. Early detection of cancer \& more effective treatment has resulted in significant declines in breast cancer related deaths and improve quality of life. Prognosis \& management of breast cancer are influenced by histomorphological variables like type, grade, tumor size and status of hormonal receptors like ER, PR and newer marker HER2/neu. ER/PR markers associated with well differentiated carcinoma \& having good prognosis. They are respond well to hormonal therapy. While HER2/neu marker is a powerful predictor for Poor prognosis as its expression is associated with poorly differentiated carcinoma having increased tumor size, high mitotic grade. Hence IHC assessment of ER, PR, HER2/neu status should be incorporated as a routine investigation along with histomorphological grading.
Funding: No funding sources.

Conflict of interest: None declared.

References

1. Parkin DM, Bray F, Ferlay J, Pisani P. Estimating the world cancer burden: Globocan 2000. Int J Cancer 2001;94:153-56.

2. Rampaul RS, Pinder SE, Elaston CW, Ellis IO. Prognostic and predictive factors in primary breast cancer and their role in patient management; the Nottingham breast team. Eur J Surg Oncol 2001;27:229-38.

3. Mori I, Yang Q, Kakudo K. Predictive and prognostic markers for invasive breast cancer. Pathol Int 2002;52, 186-94.

4. 4.Fabian CJ, Kimler BF. Selective estrogen- receptor modulators for primary prevention of breast cancer. $J$ Clin Oncol 2005;23(8):1644-55.

5. Suo Z, Risberg B, Karlsson MG, et al. The expression of EGFR family ligands in breast carcinomas. Int $J$ Surg Pathol 2002;10:91-9.

6. Frierson Jr HF, Wolber RA, Berean KW, reproducibility of the Nottingham modification of the Bloom and Richardson histologic grading scheme for infiltrating ductal carcinoma.JuanRosai. Editor. Rosai and Ackerman's Surgical Pathology. $9^{\text {th }}$ edition. St Louis: Elsevier; 2004:1826-27. 
7. Immuno histochemistry in Breast Cancer, Chapter 11 in Immuno histochemistry Technical Basis and Guidelines to Interpretation, Department of Pathology, St. Johns medical college, Bangalore. 2009;46-48.

8. Harvey JM, Clark GM, Osborne CK, Allred DC. Estrogen receptor status by immunohistochemistry is superior to the ligand binding assay for predicting response to adjuvant endocrine therapy in breast cancer. J Clin Oncol 1999; 17(5):1474-81.

9. Wolff AC, Hammond ME, Schwartz JN, et al; American Society of Clinical Oncology/College of American Pathologists. American Society of Clinical Oncology/College of American Pathologists guideline recommendations for human epidermal growth factor receptor 2 testing in breast cancer. Arch Pathol Lab Med 2007;131(1):18-43.

10. 10.Wolff AC, Hammond ME, Hicks DG, et al. Recommendations for human epidermal growth factor receptor 2 testing in breast cancer: American Society of Clinical Oncology/College of American Pathologists (ASCO/CAP) Clinical Practice Guideline Update [published online ahead of print October 7, 2013]. Arch Pathol Lab Med doi:10.5858/arpa.2013-0953-SA.

11. Frances P.O'malley, Robert Parkes, EleandorLatta, Suzanna Tzan, Tanya Zadro, Rosemary Mueller, Nona Andderson Martin Blackstein and Irene Andrulis, comparison of $\mathrm{Her}-2 / \mathrm{Neu}$ status assessed by quantitative polymerase chain reaction and immunohistochemistry. Am J Clin Pathol 2001;115:50411 .

12. 12.Russell Vang, Linda D. Cooley, Wilbur R. Harrison, Tommy Rees and Jacki Abrams, Immunohistochemical determination of $\mathrm{Her}-2 / \mathrm{Neu}$ expression in invasive breast carcinoma. Am J Clin Pathol 2000;113:669-74.

13. Sheth T, Agrawal A, Nadkami M, Palkar M, Havaldar R, Parmar V, Badwe R, Chinov R F. Hormone receptor over the last 8 years in a cancer referral centre in india:what was and what is? Indian J Pathol Microbiol

$$
\text { 2009;52:171-74 }
$$

14. Mudduwa LK. Quick score of hormone receptor status of breast carcinoma: Correlation with the other clinicopathological prognostic parameters. Indian $J$ Pathol Microbiol 2009;52:159-63.

15. Pritilal, Lee K. Tan, Beiyen Chen. Correlation of HER 2 Status with Estrogen and Progesterone Receptors and Histologic features in 3,655 invasive Breast carcinomas. Am J Clin Pathol 2005;123:541-46.

16. 16 Nisa A, Bhurgri Y, Raza F, Kayani N. Comparison of $\mathrm{ER}, \mathrm{PR}$ and Her/2 /neu reactivity pattern with histologic grade, tumor size and lymph node status in breast cancer. Asian Pac J Cancer Prev 2008;9(4):553-6

17. 17 S.B. Desai, Moonim MT, Gill AK, Punia RS, Naresh $\mathrm{KN}$, Chinoy RF, Hormone receptor status of breast cancer in India: Breast 2000;9:267-70.

18. 18 C. Allemani, M Sant, F. Berrino, T Aareleid, G Chaplain, J W Coebergh, M Colonna, P contiero, A Danzon, M Federico, L Gafa, prognostic value of morphology and hormone receptor status in breast cancer - a population based study. Br J Cancer 2004;91(7):1263-68.

19. 19 Col. V Dutta. Brig. G.S. Chopra, Lt. Col. K Sahai, Brig S.K. Nema, hormone receptors, HER - 2/Neu and chromosomal aberrations in breast cancer. MJAFI 2008;64: $11-15$.

20. Timonthy W. Jacobs, Allen M. Gown, Hadi Yaziji, Melissa J. Barnes, and Stuart J. Schnitt, Her - 2/Neu protein expression in breast cancer evaluated by immunohistochemistry. Am J Clin Pathol 2000;113:25158.

How to cite this article: Maru A., Shrivastava A., Chokshi T., Agnihotri A. Comparison of ER, PR \& HER2/neu(C-erb B2) reactivity pattern with various histomorphological patterns in patients with breast cancer. J Diagn Pathol Oncol 2018;3(4):214-47. 